\title{
Runoff generation processes in a Mediterranean research catchment (Sardinia)
}

\author{
Marcello Niedda, Mirko Castellini, Filippo Giadrossich, Mario Pirastru \\ Department of Agraria, University of Sassari, Italy
}

\section{Introduction}

In recent decades the hydrological community has increasingly improved its understanding of the runoff generation in river basins. Since Horton (1933), numerous studies have investigated these mechanisms at the plot, hillslope and catchment scale (e.g.: Betson, 1964; Dunne and Black, 1970; Pilgrim et al., 1978; Kirkby, 1978; Mosley, 1979; Beven, 1989; Anderson and Burt, 1991). The primary processes that have been observed and described to explain runoff generation in a catchment area are: (1) Hortonian Overland Flow (HOF), which occurs when rainfall intensity exceeds the infiltration capacity of the soil; (2) Saturation Overland Flow (SOF), which occurs when the storage capacity of the soil is exceeded and defines the concept of contributing saturated areas, which expand as rainfall volume increases; (3) Saturated Subsurface Flow (SSF), which occurs when the water in the soil flows along lateral paths and thus contributes to streamflow as return flow from the groundwater aquifer.

Since the 1960s researchers have appreciated the importance of SSF mechanism in runoff formation, particularly in natural landscapes. Research into catchment hydrology has led to the development of models, such as Topmodel (Beven and Kirkby, 1979) or SMR (Frankenberger et al., 1999), which aim to represent the varying extension of the saturated areas in relationship to the topography. This is one of the main factors governing stream discharge and watertable dynamics, especially in natural mountain catchments. Topography controls the flow-path geometry, the saturated area formation, depending on the water-table depths, and the SSF runoff production. Soil water content and water-table data combined with hydrograph separation techniques were the basis of the first investigations on runoff formation by Dunne and Black (1970). Improved computing and data storage capacity has played an important role in improvement the modelling of runoff formation processes, and has allowed these mechanisms to be simulated by spatially distributed mathematical models (e.g.: Abbott et al., 1986; Grayson et al., 1992; Beven et al., 1995;

Correspondence: Marcello Niedda, Department of Agraria, University of Sassari, Italy.

E-mail: niedda@uniss.it

Key words: storm-flow coefficient; runoff generation; physically based model.

CCCopyright M. Niedda et al., 2013

Licensee PAGEPress, Italy

Journal of Agricultural Engineering 2013; XLIV(s2):e8

doi:10.4081/jae.2013.s2.e8

This article is distributed under the terms of the Creative Commons Attribution Noncommercial License (by-nc 3.0) which permits any noncommercial use, distribution, and reproduction in any medium, provided the original author(s) and source are credited.
Refsgaard, 1997). However not all these processes are well understood, such as, to take one example, the mechanism by which SSF enters streams quickly enough to contribute to storm-flow (Sophocleous, 2002). One reason for this is that natural soils are very heterogeneous and respond to rainfall in different ways, as Brooks et al. (2007) pointed out in their conclusion. These problems are accentuated in the semi-arid Mediterranean climate, where runoff formation processes are particularly variable over time because of the marked irregularity in rainfall and the seasonal mismatch between evaporation and rainfall. These factors amplify oscillations in soil moisture and the depth of the water-table.

Detailed catchment studies that use distributed data collected continuously over a long period of time are uncommon, and this is particularly true in the semi-arid Mediterranean region. In response to this, a small natural catchment in Sardinia (Italy), an island at the center of the Mediterranean, was chosen as the experimental site for a long term field study. The study focused particularly on the dynamics of the runoff generation processes through field observations of rainfall, soil water content, water-table depths, and stream discharge. A physicallybased distributed rainfall-runoff model was used. The model suitability was evaluated, using integrated (outlet discharge) and distributed (water-table depths) catchment response. Water-table depths are very sensitive to the hydrological properties of the catchment, and this makes them excellent distributed indicators of model performance. Despite that, only few studies have used these measurements to evaluate the predictive ability of hydrological models (Lamb et al., 1997; Seibert et al., 1997; Molénat et al., 2005; Brooks et al., 2007; GascuelOdoux et al., 2010; Vansteenkiste et al., 2012). The aims of this work are identifying the main characteristics of runoff generation mechanisms from observations carried out in a small catchment of central Mediterranean dominated by SSF; simulating these mechanisms with a distributed hydrological modelling; and verifying if this model is appropriate for predicting simultaneously stream discharge and watertable dynamics.

\section{Materials and methods}

\section{The study area}

The study was conducted in the Baratz basin, located in NorthWestern Sardinia, Italy (Figure 1). The contributing area, at the outlet height of $40 \mathrm{~m}$ a.s.l., is $7.4 \mathrm{~km}^{2}$, the maximum catchment height is 410 $\mathrm{m}$, the mean height $156 \mathrm{~m}$ and the mean slope $15.6 \%$. The climate is semi-arid Mediterranean, with mean annual temperature of $15.8{ }^{\circ} \mathrm{C}$ and minimum and maximum mean daily temperature of $3{ }^{\circ} \mathrm{C}$ and 29 ${ }^{\circ} \mathrm{C}$, respectively. Average annual precipitation is $590 \mathrm{~mm}$ and average potential evapotranspiration is about $900 \mathrm{~mm}$. In the central-northern part of the basin the geological substratum consists of fractured sericite phyllite on the metamorphic Paleozoic base of Sardinia, while in the Southern part it is Permian sandstone and conglomerates of 
alluvial deposits, with Permo-carboniferous and Triassic volcanic insertions. The morphology of the basin is narrow valleys covered in woods. The soils in the North of the basin were either thin or of medium depth, from loam to loamy sand, sub-acid, and partially desaturated. The soils in the South were deep, sandy loam in the surface layers and from sandy clay loam to clay in the deeper layers, and from sub-acid to acid. The most widespread land-use was natural pasture, followed by deciduous forest and maquis. These characteristics are reported in Table 1.

\section{The instrumentation}

An automatic station was set up in 2008 , located at the catchment outlet, with sensors for rainfall, air temperature and relative humidity, wind velocity, net solar radiation, atmospheric pressure, soil moisture, groundwater level and temperature, and depth and velocity of surface flow, described in detail in Pirastru and Niedda (2013). All automatic measurements were executed every $300 \mathrm{~s}$, and were logged using a CR1000 Campbell Scientific Inc. datalogger, a SonTek Argonaut-SW current meter and three Schlumberger mini-divers. A V-notch was installed on the stable bed of a trapezoidal concrete channel, immediately downstream from the current meter, to stabilize the low flow and facilitate the measurements. Groundwater levels were taken in five boreholes located in the valley bottom, as shown in Figure 1a, by using mini-divers and manual measurements every one-two weeks.

\section{Storm-flow coefficients}

From the four year series of data, from 2008 to 2012, the storm-flow coefficients at the event scale were computed. All the events more than $5 \mathrm{~mm}$ of rain, and separated by time intervals of more than 24 hours with less than $1 \mathrm{~mm}$ of rain, were chosen. Sixty-nine such events were identified during this period, and the following variables were calculated for each of them: rainfall depth, maximum hourly rainfall intensity, storm-flow discharge, storm-flow coefficient, base-flow discharge, the average soil moisture (the first metre) and the water-table depth at the valley bottom at the start of the event. The storm-flow discharge was separated from the base-flow discharge using the classic method of Hewlett and Hibbert (1967). Beginning from the foot of the rising limb of the streamflow hydrograph, base-flow was then increased by a constant value until it intersected the falling limb of the hydrograph, which indicated the end of the storm-flow event. An increment of the baseflow of $10 \mathrm{l} / \mathrm{s}$ per day was chosen after analysis of all the hydrographs observed in the basin. Figure 2a shows the seasonal evolution of the rainfall depths for each of the 69 chosen events during the four years of monitoring. Winter was the season with the greatest number of events (40\%), and summer the fewest (9\%). The other events were equally divided between spring and autumn, although the rainfall depths in autumn were greater, with a maximum value of $108 \mathrm{~mm}$. Figure 2b shows the seasonal evolution of the storm-flow coefficient for each event. The highest values were clearly concentrated in winter. In the other seasons, and particularly from the middle of March to the middle of November, even rainfall which had higher depths than those of the winter did not generate significant storm-flow discharge, with storm-flow coefficients of less than $2 \%$.

The correlations between the storm-flow coefficient and the maximum hourly rainfall intensity and also the base-flow were analyzed. The first correlation was found to be statistically non-significant $(r=-$ 0.1 ), which indicates that rainfall intensity had little influence on hydrological response in forested basins, in agreement with the studies by Hewlett et al. (1977) and Lana-Renault et al. (2007). The correlation between the storm-flow coefficient and the base-flow was, however, statistically significant $(r=0.76)$, which is in line with the results obtained by Latron and Gallart (2007) and Lana-Renault et al. (2007) for other

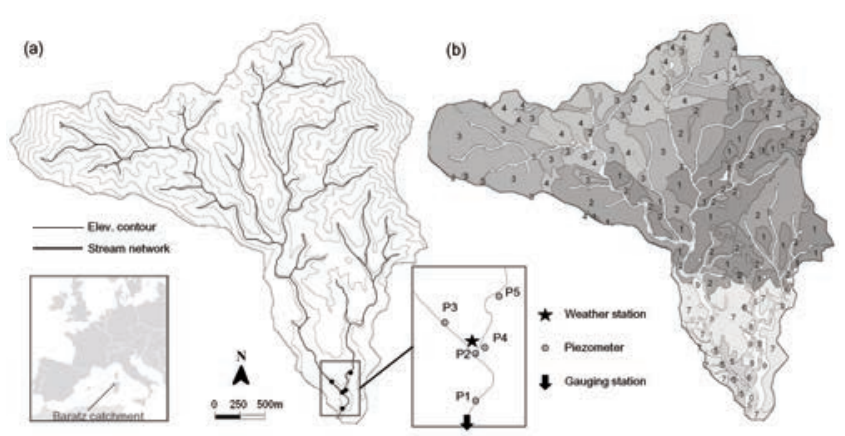

Figure 1. (a) Map of the Baratz catchment in North-Western Sardinia, Italy (elevation contour interval: $25 \mathrm{~m}$ from 50 to $400 \mathrm{~m}$ asl) and location of the main monitoring instruments; (b) map of soil and land-use type (classes in Table 1).

Table 1. Soil and land-use properties for the Baratz basin.

\begin{tabular}{|c|c|c|c|c|c|c|c|c|c|c|c|}
\hline Type (Figure lb) & 1 & 2 & 3 & 4 & 5 & 6 & 7 & 8 & 9 & 0 & $\mathrm{~s}$ \\
\hline Geology & \multicolumn{4}{|c|}{ Paleozoic metamorphic } & \multicolumn{2}{|c|}{$\begin{array}{c}\text { Permian } \\
\text { sandstone }\end{array}$} & \multicolumn{3}{|c|}{$\begin{array}{c}\text { Pliocene alluvial } \\
\text { deposits }\end{array}$} & \multicolumn{2}{|c|}{$\begin{array}{c}\text { Olocene alluvial } \\
\text { deposit }\end{array}$} \\
\hline Surface cover & Pasture & Maquis & Forest & Pasture & Forest & & Pastur & & Maquis & Pasture & Riparian \\
\hline Soil thickness $H(\mathrm{~m})$ & \multicolumn{2}{|c|}{0.25} & \multicolumn{2}{|c|}{0.35} & \multicolumn{2}{|c|}{0.5} & 1.0 & 0.5 & 0.3 & \multicolumn{2}{|c|}{3.0} \\
\hline Texture & \multicolumn{2}{|c|}{ Loam } & \multicolumn{2}{|c|}{ Loamy sand } & \multicolumn{5}{|c|}{ Sandy loam } & Loam & Sand \\
\hline $\begin{array}{l}\text { Soil porosity } \\
\left(\mathrm{fm}^{3} / \mathrm{cm}^{3}\right)\end{array}$ & \multicolumn{2}{|c|}{0.463} & \multicolumn{2}{|c|}{0.437} & \multicolumn{5}{|c|}{0.453} & 0.463 & 0.437 \\
\hline $\begin{array}{l}\text { Soil moisture at }-33 \mathrm{kPa} q_{n} \\
\left(\mathrm{~cm}^{3} / \mathrm{cm}^{3}\right)\end{array}$ & \multicolumn{2}{|c|}{0.270} & \multicolumn{2}{|c|}{0.125} & \multicolumn{5}{|c|}{0.207} & 0.270 & 0.091 \\
\hline $\begin{array}{l}\text { Saturated hydraulic } \\
\text { conductiv } K_{s}(\mathrm{~mm} / \mathrm{h})\end{array}$ & \multicolumn{2}{|c|}{12} & \multicolumn{2}{|c|}{70} & \multicolumn{5}{|c|}{30} & 12 & 220 \\
\hline Relative area (\%) & 19.1 & 22.3 & 22.0 & 14.7 & 1.1 & 0.5 & 8.7 & 0.9 & 1.8 & 0.3 & 8.5 \\
\hline
\end{tabular}


small Mediterranean basins. Because base-flow is governed by the soil moisture and the water-table depth, this correlation shows the influence of the pre-event values of these variables on the rainfall-runoff processes. Figures $2 \mathrm{c}$,d,e,f show the seasonal dynamics for average moisture in the first metre of soil (four TDR probes) and the depth of the water-table at piezometers P1, P2 and P4. These figures show some regularities in each season, despite the great variability in rainfall and stream discharge from one year to another. The differences in soil moisture and the water-table depth in the four years are more to do with the rapid autumnal increase and the rapid decrease in summer, and less with the maximum and minimum values. Figure 3 shows the relationships between the storm-flow coefficients and soil moisture and the water-table depth at the start of each event, at piezometer P1 near the basin outlet. The correlation is very high, which agrees with those for their seasonal evolutions. The storm-flow coefficients increase as soil moisture increases and the water-table depth in the valley bottom decreases. Storm-flow coefficients were greater than $2 \%$ only when soil moisture was more than $30 \%$ and the water-table depth less than $1 \mathrm{~m}$, a depth which corresponded with that of the streambed.

\section{Runoff generation mechanisms}

The monitoring with TDR probes indicates that soil moisture in winter was higher than $30 \%$, with peak levels of over $40 \%$ during the most intense rainfall events (Figure 2c). In this season the water-table was at the same level as the streambed, about 1-1.5 metres deep, with higher peaks during the most intense rainfall events (Figure 2d,e,f). The height of the peaks also increased with the distance of the piezometers from the streambed. This was capable of draining the nearest piezometers P1 and P2, a few metres from the streambed, more rapidly than it did P4, which was 17 metres from the streambed. Only at piezometer P4 did the water-table reach the ground surface and the soil become saturated for brief periods, as shown in Figures 2d,e,f. As can be seen in Figure 2b, the winter period from November to March was the only with high storm-flow coefficients ( $>2 \%$ ). In this period of rapid runoff after rainfall, the storm-flow peaks were a result of the SOF mechanism over large saturated areas, which are controlled by the SSF. The high runoff during the recession after the rainfall shows that the SSF enters streams quickly enough to contribute to discharge, in the form of storm-flow.

In spring, the soil moisture of the surface layers begins to decline rapidly, due to the great increase in evapotranspiration, until they reach minimum levels in late spring. The water-table in the valley bottom stays at the same level as the streambed. This serves to feed the streambed, generating the slow response and the long recessions typical of the base-flow. The generation mechanism is the exfiltration of the SSF within the soil matrix. Only in summer does the water-table begin to fall to a greater depth than the streambed of the valley bottom.
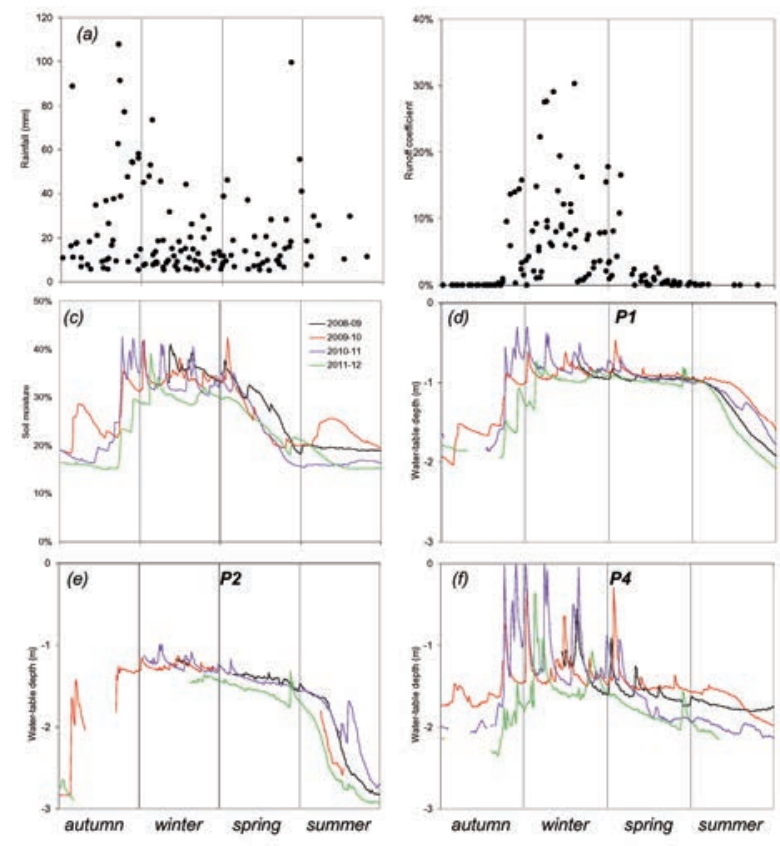

Figure 2. Seasonal patterns throughout the years 2008-2012 of (a) the rainfall depth; (b) the maximum hourly rainfall intensity; and (c) the storm-flow coefficient.

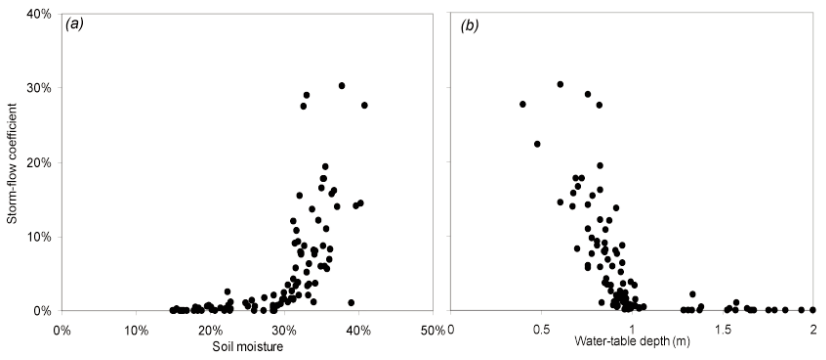

Figure 3. Relationships between the storm-flow coefficients and (a) the average soil moisture, observed near P4; and (b) the water-table depth at the start of each event, observed at piezometer P1.

Table 2. Annual components of the catchment water balance: $P$ precipitation, $R$ runoff, $R / P$ runoff coefficient, $E T$ actual evapotranspiration, $E$ evaporation from surface interceptions, $I$ percolation; and efficiency coefficients $E F$ for the four hydrological years of continuous simulation

\begin{tabular}{|c|c|c|c|c|c|c|c|c|}
\hline \multirow[b]{2}{*}{ Water year } & \multicolumn{2}{|c|}{ Measured } & \multicolumn{6}{|c|}{ Simulated } \\
\hline & $P(\mathrm{~mm})$ & $R(\mathrm{~mm})$ & $R / P(\%)$ & $E T(\mathrm{~mm})$ & $E(\mathrm{~mm})$ & $I(\mathrm{~mm})$ & $R(\mathrm{~mm})$ & $E F$ \\
\hline 2008-2009 & 775 & $97.7^{*}$ & 12.6 & 435.4 & 88.2 & 92.6 & 124.6 & 0.87 \\
\hline 2009-2010 & 700 & $32.2^{*}$ & 4.6 & 490.6 & 108.5 & 36.0 & 51.3 & -1.30 \\
\hline 2010-2011 & 801 & 195.4 & 24.3 & 437.6 & 91.1 & 107.3 & 176.5 & 0.82 \\
\hline 2011-2012 & 596 & 15.1 & 2.5 & 473.7 & 84.9 & 31.1 & 31.2 & -1.50 \\
\hline av.2008-2012 & 718 & 91.3 & 11.9 & 459.3 & 93.2 & 66.8 & 95.9 & 0.83 \\
\hline
\end{tabular}

* Missing observed runoff data filled in with simulated values. 
The base-flow stops and the streambed dries up until the autumn recovery. As shown in Figure 2, summer and autumn are characterised by low water-table heights and low soil moisture. This usually lasts until the middle of November when, after the most intense rainfall of the year, both these values increase rapidly and reach their annual maximum values. Before this, in summer and early autumn, there was no measurable discharge, despite various rainfall events, some of which were very intense. This can be seen from the seasonal evolution of the rainfall and storm-flow coefficients in Figures $2 \mathrm{a}$ and $2 \mathrm{~b}$. This shows that during these seasons the non-saturated soils, which extend towards the valley bottom, are able to absorb large, high-intensity rainfall events. This means that the HOF is a negligible mechanism in this environment.

\section{The SSFR model}

The Saturated Subsurface Flow Routing model (SSFR) is a GISbased distributed model for the continuous simulation of the coupled subsurface-channel flow, which neglects the vertical distribution of soil moisture and the unsaturated flow processes. The SSFR model used in this project is a modified version of a previous model, which was developed for basins with steep and shallow soil in Mediterranean environment (Niedda, 2000; Niedda and Pirastru, 2012; Niedda and Pirastru, 2013). SSFR is based on the modelling principles of Grayson et al. (1992), who minimized the number of parameters and processes represented, so that the simplified structure of the model is in balance with the amount of available field data, while the flow components are physically based. Surface interception and soil moisture store dynamics, percolation into the bedrock, evapotranspiration, 1D open channel flow and 2D horizontal saturated subsurface flow are modelled, based on the water balance at each cell of the grid discretization, and for each time step. Conceptual representation of the vertical and lateral water flows for each grid-cell are shown in Figure 4. Since HOF is a negligible mechanism, all excess precipitation $P_{e}$ from interception storage $S$ infiltrates, unless the soil thickness $H$ is saturated (Frankenberger et al., 1999; Moore and Grayson, 1991; Wigmosta et al., 1994). Soil moisture varies between soil porosity and residual content, set at zero for a forest ecosystem. It is assumed that soil thickness first becomes wet up to the moisture content $\theta_{33}$, held at $-33 \mathrm{kPa}$ matric potential. Only when the soil moisture exceeds 33 do excess volumes constitute an input for the SSF governed by Darcy's law. Following Dupuit's approximation, the mass and momentum conservation equations for unsteady 2D saturated subsurface flow were used, with parameters the soil hydraulic conductivity decreasing with depth, from $K_{S}$ at the surface

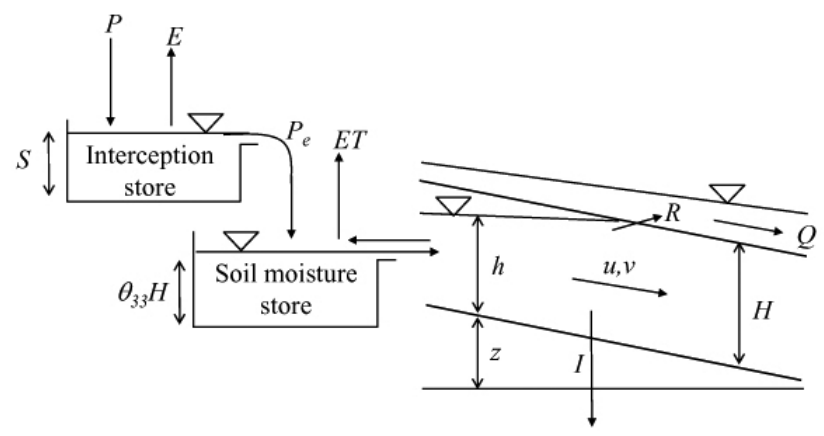

Figure 4. Conceptual representation of the vertical and lateral flows between soil, bedrock, surface and atmosphere domains simulated by the distributed catchment hydrologic model at each cell of the grid discretization. and 0 at the bottom. When the height of the water-table $h$ exceeds a threshold value ${ }_{i}$, the soil percolation $I$ is activated. When the height of the water-table intercepts the ground surface $(h>H)$, saturationexcess $R$ is an input in surface runoff $Q$. In accordance with the SaintVenant equations and the kinematic approximation, the mass and momentum conservation equations for 1D gradually varied surface flow were used, with parameter the Manning's roughness. The partial differential equations for surface and subsurface flow, described in Niedda and Pirastru (2012), were solved by conventional finite difference schemes. The same numerical discretization was used for the soil and channel flow components, the space cells of grid-DEM and the other landscape parameters.

\section{Model parameterization}

The model input are digital elevation data, soil and land-use maps, precipitation, and evapotranspiration. The terrain properties were organized into eleven types, as shown in Figure 1b, identified as areas with the same soil depth, texture, land-use and geology (see Table 1). Manning's roughness coefficient $n=0.03 \mathrm{~m}^{-1 / 3} \mathrm{~s}$ was used. The interception storage capacity $\mathrm{S}$ was determined from the Leaf Area Index (LAI): $\mathrm{S}(\mathrm{mm})=0.2 \cdot \mathrm{LAI}$ (Dickinson et al., 1991), with $\mathrm{LAI}=2$ for pasture and 10 for maquis and forest. Soil porosity $\varphi$, moisture content $\theta_{33}$ and hydraulic conductivity KS were estimated from soil texture (Rawls et al., 1993); but the effective hydraulic conductivity was obtained as $\alpha \cdot \mathrm{KS}$, where $\alpha$ is a fitting amplification factor. This step was applied because the hydrological conservation equations are derived at the point-scale within a differential control volume, and their use at catchment scales may require effective parameters that differ from those estimated in field plots or laboratory studies.

The simple percolation mechanism used for the Baratz basin was optimised by the calibration procedure, as information on the hydraulic properties of the fractured bedrock was unavailable. Unlike other models, in which percolation feeds a deep aquifer generally represented as a linear reservoir which feeds the base-flow (Frankenberger et al., 1999; Gascoin et al., 2009), in this case percolation becomes a net loss subtracted from the soil water content of each cell. This hypothesis is suggested by the fact that in the Baratz basin the upstream aquifer of the fractured metamorphic rock is not connected to the soil of the valley bottom. The fractured bedrock is, indeed, only present in the hillier central-northern part of the basin (about $80 \%$ of the area), while in the southern flatter part, where there is the basin outlet, the bedrock consists of Permian sandstone which has very low permeability and percolation is not activated.

The actual evapotranspiration $E T$ of the different canopy covers was calculated from reference evapotranspiration PET using the ECOWAT model: $E T=k_{m} \cdot k_{v} \cdot k_{d} \cdot k_{s} \cdot P E T$. The details of the ECOWAT model are described in Spano et al. (2009), where the model was tested at a wide range of sites, including one which is very close to Baratz catchment (7 $\mathrm{km}$ away). As in this study, microclimate factor $k_{m}$ and vegetation factor $k_{v}$ are set at 1.2 and 0.92 , respectively, $k_{d}$ is set to 0.8 for pasture and 0.6 for maquis and forest, and $k_{s}=\sin (\theta / \theta c \cdot \pi / 2)$ for $\theta<\theta_{c}$, where $\theta_{c}=0.5 \cdot \theta_{33}$.

The continuous simulation was run from 2008 to 2012, using a timestep equal to $300 \mathrm{~s}$ and a space-step equal to $5 \mathrm{~m}$. The soil was considered completely dry as an initial condition, as there had been severe droughts in the previous periods. Fit calibration process was applied in an attempt to make model predictions consistent with both the observed stream discharge and the distributed water-table depths. The goodness-of-fit was evaluated using the coefficient of efficiency $E F$ (Nash and Sutcliff, 1970) for hourly stream discharge. Three parameters were considered for the model calibration: the soil conductivity amplification factor $\alpha$; the percolation velocity into the fractured 
bedrock $I$; and the water-table height threshold $H_{i}$ above which percolation begins.

\section{Results and discussion}

\section{Calibration results}

The comparisons between the simulated and observed streamflow at the basin outlet are shown in Figure 5, and water-table depths at each piezometer in Figure 6. The water balance between September 2008 and September 2012 (Table 2), shows that total precipitation $P$ was divided up as follows: $64 \%$ actual evapotranspiration $E T, 13 \%$ evaporation from surface interceptions $E, 13.4 \%$ surface runoff $R$ and $9.3 \%$ soil percolation $I$. In the first water year, there was a high value of $P$, a runoff coefficient of $12.6 \%$ and a good efficiency of the simulation of the stream discharge, as shown in Table 2. In 2009-10, despite $P$ was above the long-term average, $E T$ was high and the runoff coefficient small. The simulation overestimated the stream discharge, and so was little efficient. In 2010-11 there was the highest $P$, the highest runoff coefficient and a good efficiency of the simulation. Finally, in 2011-12, when there was low $P$ and the $E T$ was high, the simulation overestimated the small observed stream discharge and was little efficient.

Two amplification factor values were obtained: $\alpha=100$ for maquis and forest, and $\alpha=5$ for pasture and riparian areas. These calibrated values are much larger than the soil conductivities found in the literature at the point scale, and similar in magnitude to the values found by Dunne and Black (1970) and Brooks et al. (2004) in their hillslope trench studies of forested soil horizons. These values take into account different effects, among which the macropore flow, mainly present for maquis and forest, and the parameter scaling due to the topography resolution adopted in the numerical scheme (Niedda, 2004; Jana and Mohanty, 2012). Percolation velocity was obtained by calibrating the simulated storm-flow peaks with those that were measured. The optimised value $I=4 \mathrm{~mm} / \mathrm{h}$ was found to be compatible with the conductivities of the fractured rock that are estimated in the literature, though these vary widely (Smith and Wheatcraft, 1993; Pirastru and Niedda, 2010). The water-table height threshold $H_{i}=0.15 \mathrm{~m}$, above which percolation begins, was obtained by attempting to close the poly-annual water balance at the basin scale. These parameter values show that deep percolation, physically justified by the presence of highly fractured bedrock in the Baratz basin, is a fundamental part of the model. The percolation was a key component of the catchment water balance, which is of the same order as surface runoff and significantly reduces the storm-flow. Without this component, the simulated storm-flow peaks would have been one order higher than those actually measured. The latter were, indeed, significantly lower than those for similar basins with impermeable bedrock.

Despite great differences in annual rainfall and stream discharge, one can identify common characteristics in the pattern of the watertable, simulated with relatively high efficiency (Figure 6a). During winter and spring the water-table is close to the streambed incised in the valley bottom, and this is well simulated. Most difficulty was experienced in simulating the water-table during the gradual recession in the dry season, due to the effects of $E T$, and the successive autumnal rise. In general the simulated recession during the dry season was in advance of the observed results, while during the autumnal rise the simulation lagged behind the observed results. The spatial variations in the water-table levels show that there were great differences in the rate and the size of the recession during the dry period. The simulation reproduced the recession found by piezometer P1 very well, while it underestimated the results for P2 and overestimated those for P4
(Figure 6). The simulation estimated most efficiently the results for P1, than P2 and P4, also because the calibration was optimised for the stream discharge measured at the basin outlet, where P1 is situated. It is important to note that the piezometers closest to one another, P2 and $\mathrm{P} 4$, showed the greatest differences in the evolution of the water-table, with rapid falls in summer in $\mathrm{P} 2$ and much slower in $\mathrm{P} 4$, above all in the first year of monitoring. These great differences in the behaviour of the water-table, even over a short distance, are probably due to the complex geometry of the bedrock surface and the alluvial strata with different hydrological characteristics. The fact that the two piezometers are on different branches of the stream network which join just before the basin outlet may also have an influence on these differences. These characteristics are very difficult to survey in detail at the basin scale and therefore to represent in the model.

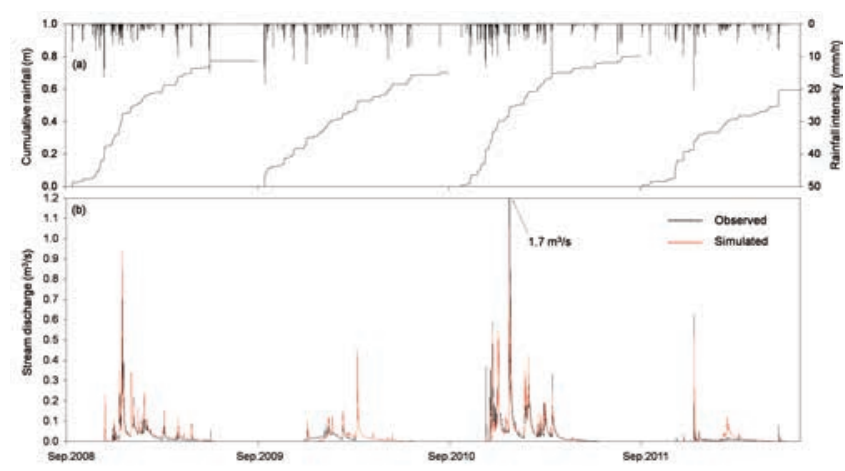

Figure 5. Comparison between (a) cumulative rainfall, rainfall intensity and (b) simulated and observed hourly stream discharge at the basin outlet from September 2008 to June 2012.

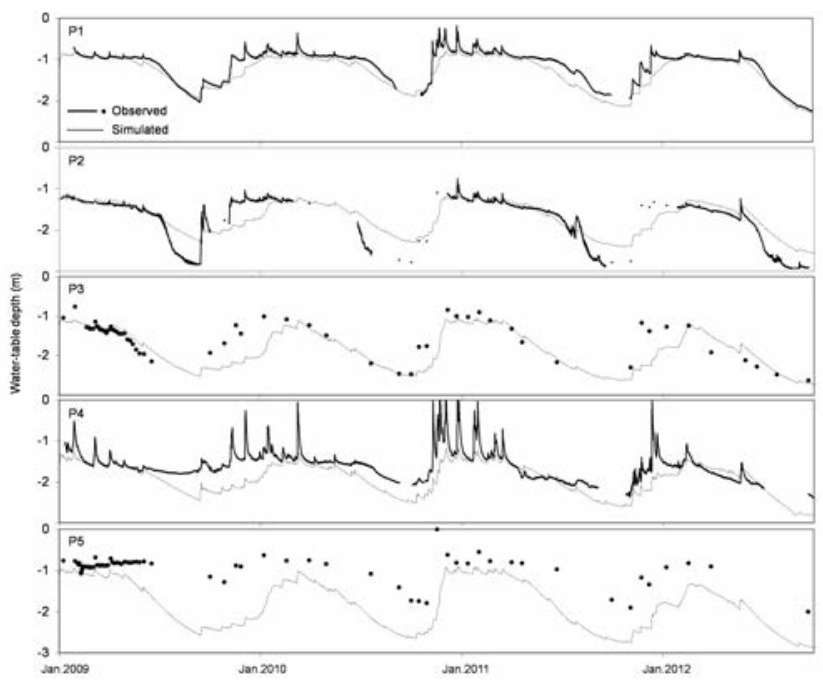

Figure 6. Observed and simulated water-table depth at the five piezometers from January 2009 to September 2012. 


\section{Discussion}

The SSFR model simulated the hydrological processes of the Baratz basin continuously for a series of four years. It used a limited number of parameters to represent the subsurface and surface flow, generated through the SOF and SSF mechanisms. The main simplifications were with respect to the vertical distribution of soil moisture, the unsaturated flow and the HOF. Ignoring these processes allowed us to reduce the simulation of the 3D subsurface flow to a 2D sub-horizontal scheme, limited only to the saturated part of the soil. This was very advantageous for implementing and resolving the numerical scheme. This simplified scheme, despite the smoothing effect on the observed data of the water-table, was still able to reproduce the runoff generation through exfiltration of SSF and through SOF over the variable saturated areas, so that stream discharge at the basin scale was efficiently simulated. One of the principal objectives of this work was to evaluate the errors which occur when simulating stream discharge and shallow water-table dynamics with these modelling hypotheses. Theseassumptions are generally satisfactory in forested hillslopes where the soil is thinner and there is high hydraulic conductivity, due to the presence of a thick network of macropores. Experimental observations have, indeed, always shown that in such environments SSF is dominant, the infiltration capacity of the soil exceeds rainfall intensity, and that overland flow is extremely rare (Hewlett and Hibbert, 1967; Dunne and Black, 1970). One major critical problem whether these modelling hypotheses can be used for valley bottoms, where the thickness of alluvial soils may be greater, and deforesting and agricultural practices commonly used in the Mediterranean have reduced the drainage capacity of the surface soil. In such cases, the unsaturated soil between the ground surface and the water-table may have a great influence both on the recharge, and thus on the SSF of the valley bottom, and on the HOF mechanism.

In this respect, the water-table depths observed in the valley bottom showed that intense rain in the wet seasons, when the water-table was near the soil surface, resulted in a rapid rise in its level, and SSFR was unable to reproduce this in its entirety. This fast response, observed by many authors (Molénat et al., 2005; Brooks et al., 2007; Lana-Renault et al., 2007), was because of the high water content of the unsaturated soil near the ground surface in winter. This make the effective porosity very small, so that only small amounts of water are necessary to saturate the whole soil profile (Pirastru and Niedda, 2012). The SSFR model does not represent the water content of unsaturated soil greater than ${ }_{33}$, showing pre-event soil moisture as being less than the actual value, and thus underestimates the rise of the water-table, as shown in Figure 6 . The piezometers also showed that the amount of rise during stormflow in wet seasons was proportional to the distance from the streambed. This can be seen from the smaller peaks at P1 and P2, which were only a few metres from the stream, and the larger peaks at P4, $17 \mathrm{~m}$ from the stream (Figure 1). This difference is due to the hydraulic gradients of the water-table, which feeds the stream discharge through the lateral SSF. The fact that the rapid water-table rises could not be fully reproduced by the model meant that the simulated gradients of the water-table were lower that those observed. Therefore, in order to generate the observed streamflow, a higher value of $K_{S}$ was necessary in simulating SSF. This is one of the reasons for increasing the calibrated values of soil conductivity at the basin scale in SSFR.

By contrast in spring, when ET is the active process that quickly dries the surface soil while the water-table is still high in the valley bottom, as shown in Figure 2, there are high vertical gradients in the soil water potential. The SSFR model was also unable to simulate this, as it cannot represent soil water content of less than $\theta_{33}$ before the watertable level reaches zero. As a result, since the modelled ET subtracts water first from the water-table and then from the soil moisture below ${ }_{33}$, the simulated water-table depths tend to anticipate the start of the recession observed in field, as shown in Figure 6. The rapid rise of the water-table in response to intense autumnal rainfall, but when its level is low and the soil was still dry, is perplexing. Here generally the simulation tended to delay the time at which the water-table rises. One reason for this is because the simulated volume of the infiltrated water are retained throughout the whole depth of the soil layers until $\theta_{33}$ is reached, and only then does the rise of the water-table begin. The mechanism by means of which the water-table can rise rapidly even when its level is low and the soil is still dry is a matter of debate. It may be due to both the effect of the macropores and the lateral contribution of wet soil under the streambed (Sophocleus, 2002). It may also be influenced by the vertical distribution of the drainable porosity and the hydraulic conductivity, which locally control the water-table variations and water flux. SSFR takes into account decreasing hydraulic conductivity with depth and uniform drainable porosity. Different vertical distribution would have to be verified by a quantity of field data generally too large to be collected at the catchment scale. These are complex processes that still need to be investigated experimentally and simulated by modelling. This lack of information is probably one of the reasons that less simplified models than the one we used, which simulate the 3D unsaturated flows, such as e.g. MIKE SHE (Abbott et al., 1986) or ParFlow (Kollet and Maxwell, 2006), produce equally satisfactory results at the basin scale (Vansteenkiste et al., 2012). Indeed, as stated by Brooks et al. (2007), the accuracy of any distributed hydrologic model is limited by our ability to characterize the spatial heterogeneity in soil hydraulic properties.

\section{Conclusions}

In this small Mediterranean research catchment, dominated by the SSF mechanism of runoff production, the relationship between rainfall and storm-flow depth at the event scale confirmed the strong non-linearity of these two variables, as has also been shown in other Mediterranean catchments (Ceballos and Schnabel, 1998; MartınezMena et al., 1998; Latron and Gallart, 2007, Lana-Renault et al., 2007). The storm-flow coefficient was mainly related to soil moisture and water-table depth, with values higher than $2 \%$ only during the wet winter period, suggesting that subsurface flow played a primary role in runoff production at the basin scale. The seasonal dynamics of soil moisture, water-table depth and stream discharge observed at the valley bottom of the Baratz catchment enabled us to recognize three seasonal periods of the water year, characterised by different dominant runoff formation processes: 1) summer and autumn, which have high water-table depths, low soil moisture and no stream discharge even when there is intense rainfall, which infiltrates into the soil and increases the water content and water-table level, without producing HOF; 2) winter, which has low water-table depths, high soil moisture and storm-flow generated by the SOF over saturated areas and by the SSF through pipes, macropores and seepage zones in the soil; 3) spring, which has low water-table depths, low soil moisture and slow base-flow generated by the exfiltration of SSF through the soil matrix. These results indicate that the dominant mechanism in runoff formation is the SSF, which gives rise to base-flow, controls the saturated areas formation and enters streams quickly enough to contribute to the storm-flow together with the SOF, while the HOF mechanism can be ignored. 


\section{References}

Abbott M.B., Bathurst J.C., Cunge J.A., O'Connel P.E., Rasmussen J. 1986. An introduction to the European hydrological systems-systeme hydrologique Europeen, 'SHE'. 2. Structure of a physically based distributed modelling system. Journal of Hydrology 87:61-77.

Anderson M.G., Burt T.P. 1991. Process studies in hillslope hydrology: an overview, in: Process studies in hillslope hydrology, Wiley \& Sons, Chichester: 1-8.

Betson R.P. 1964. What is watershed runoff?. J. Geophys. Res. 69:1541-1552.

Beven K., Lamb R., Quinn P., Romanowicz R., Freer J. 1995. TOPMODEL. In Computer Models of Watershed Hydrology, Singh V.P. (Ed.), Water Resour. Publ., Highlands Ranch, Colo.:627-668.

Beven K.J., Kirkby M.J. 1979. A physically based variable contributing area model of basin hydrology. Hydrological Sciences Bulletin 24:43-69.

Beven K.J. 1989. Interflow, in: Unsaturated Flow in Hydrologic Modelling Theory and Practice, edited by: Morel-Seytoux H.J., Kluwer Academic Publishers:191-219.

Brooks E.S., Boll J., McDaniel P.A. 2004. A hillslope-scale experiment to measure lateral saturated hydraulic conductivity. Water Resources Research 40: W04208. doi:10.1029/2003WR002858.

Brooks E.S., Boll J., McDaniel P. 2007. Distributed and integrated response of a geographic information system-based hydrological model in the eastern Palouse region, Idaho. Hydrological Processes 21:110-122.

Ceballos A., Schnabel S. 1998. Hydrological behaviour of a small catchment in the dehesa landuse system (Extremadura, SW Spain). J. Hydrol. 210:146-160.

Dickinson R.E., Henderson-Sellers A., Rosenzweig C., Sellers P.J. 1991. Evapotranspiration models with canopy resistance for use in climate models, a review. Agricultural and Forest Meteorology 54:373-388.

Dunne T., Black R.D. 1970. An experimental investigation of runoff production in permeable soils. Water Resources Research 6:478-490. doi: 10.1029/WR006i002p00478.

Frankenberger J.R., Brooks E.S., Todd Walter M., Walter M.F., Steenhuis T.S. 1999. A GIS-based variable source area hydrology model. Hydrological Processes 13:805-822. doi: 10.1002/(SICI)1099-1085(19990430)13.

Gascoin S., Ducharne A., Ribstein P., Carli M., Habets F. 2009. Adaptation of a catchment-based land surface model to the hydrogeological setting of the Somme River basin (France). J. Hydrol. 368:105-116.

Gascuel-Odoux C., Weiler M., Molénat J. 2010. Effect of the spatial distribution of physical aquifer properties on modelled water table depth and stream discharge in a headwater catchment. Hydrol. Earth Syst. Sci. 14:11791194.

Grayson R.B., Moore I.D., McMahon T.A. 1992. Physically based hydrologic modeling 1. A terrain-based model for investigative purposes. Water Resources Research 28:2639-2658.doi: 10.1029/92WR01258.

Hewlett J.D., Fortson J.C., Cunningham G.B. 1977. Effect of rainfall intensity on storm flow and peak discharge from forest land. Water Resources Research 13(2):259-266.

Hewlett J.D., Hibbert A.R. 1967. Factors affecting the response of small watershed to precipitation in humid areas. In: Sopper W.E., Lull H.W. (Eds.), International Symposium of Forest Hydrology. Pergamon Press: 275-290.

Horton R.E. 1933. The role of infiltration in the hydrologic cycle. Trans. American Geophysical Union 14:446-460.

Jana R.B., Mohanty B.P. 2012. On topographic controls of soil hydraulic parameter scaling at hillslope scales. Water Resources Research 48: W02518, doi:10.1029/2011WR011204.

Kirkby M.J. (Eds.) 1978. Hillslope hydrology, Wiley and Sons, Chichester.

Kollet S.J., Maxwell R.M. 2006. Integrated surface-groundwater flow modeling: A free-surface overland flow boundary condition in a parallel groundwater flow model. Adv. Water Resour. 29(7):945-958.

Lamb R., Beven K., Myrabø S. 1997. Discharge and water-table predictions using a generalized TOPMODEL formulation. Hydrological Processes 11:1145-1168.

Lana-Renault N., Latron J., Reguiés D. 2007. Streamflow response and watertable dynamics in a sub-Mediterranean research catchment (Central Pyrenees). J. Hydrol. 347:497-507.

Latron J., Gallart F. 2007. Seasonal dynamics of runoff-contributing areas in a small mediterranean research catchment (Vallcebre, Eastern Pyrenees). J. Hydrol. 335 (1-2):194-206.

Martınez-Mena M., Albaladejo J., Castillo V. 1998. Factors influencing surface runoff generation in a Mediterranean semiarid environment: Chicamo watershed, SE Spain. Hydrological Processes 12:741-754.

Molénat M., Gascuel-Odoux C., Davy P., Durand P. 2005. How to model shallow water-table depth variations: the case of the Kervidy-Naizin catchment, France. Hydrological Processes 19(4):901-920.

Moore I.D., Grayson R.B. 1991. Terrain-based catchment partitioning and runoff prediction using vector elevation data. Water Resources Research 27:1177-1191.doi: 10.1029/91WR00090.

Mosley P.M. 1979. Streamflow generation in a forested watershed, New Zealand. Water Resources Research 15:795-806.

Nash J.E., Sutcliffe J.E. 1970. River flow forecasting through conceptual models, part I - a discussion of principles. J. Hydrol. 10:282-290. doi: 10.1016/0022-1694(70)90255-6.

Niedda M. 2000. Simulation of ground-water flow in steep basin with shallow surface soil. J. Hydraul. Eng. 126:670-678.

Niedda M. 2004. Upscaling hydraulic conductivity by means of entropy of terrain curvature representation. Water Resources Research 40: W04206. doi:10.1029/2003WR002721.

Niedda M., Pirastru M. 2012. Hydrological processes of a closed catchmentlake system in a semi-arid Mediterranean environment. Hydrological Processes, doi: 10.1002/hyp.9478.

Niedda M., Pirastru M. 2013. Modelling stream discharge and shallow watertable dynamics in a Mediterranean natural catchment (Sardinia). Hydrological Processes, in press.

Pilgrim D.H., Huff D.D., Steele T.D. 1978. A field evaluation of subsurface and surface runoff. II. Processes. J. Hydrol. 38:319-341.

Pirastru M., Niedda M. 2010. Field monitoring and dual permeability modelling of water flow through unsaturated calcareous rocks. J. Hydrol. 392 40-53. doi: 10.1016/j.jhydrol.2010.07.045.

Pirastru M., Niedda M. 2013. Evaluation of the soil water balance in an alluvial flood plain with a shallow groundwater table. Hydrological Sciences Journal, 58:898-911, doi 10.1080/02626667.2013.783216.

Rawls W.J., Ahuja L.R., Brakensiek D.L., Shirmohammadi A. 1993. Infiltration and soil water movement. In Handbook of hydrology, Maidment D.R. (ed.), McGraw-Hill, New York, 5.1.

Refsgaard J.C. 1997. Parameterisation, calibration and validation of distributed hydrological models. J. Hydrol. 198:69-97.

Seibert J., Bishop K.H., Nyberg L. 1997. A test of TOPMODEL's ability to predict spatially distributed groundwater levels. Hydrological Processes 11:11311144.

Smith L., Wheatcraft S.W. 1993. Groundwater flow. In: Maidment D.R. (Ed.) Handbook of Hydrology, McGraw-Hill, Inc., New York. 6.1-6.58.

Sophocleous M. 2002. Interactions between groundwater and surface water: The state of the science. Hydrogeology Journal 10:52-67.

Spano D., Snyder R.L., Sirca C., Duce P. 2009. ECOWAT-A model for ecosystem evapotranspiration estimation. Agricultural and Forest Meteorology 149:1584-1596. doi:10.1016/j.agrformet.2009.04.011.

Vansteenkiste T., Tavakoli M., Ntegeka V., Willems P., De Smedt F., Batelaan 0. 2012. Climate change impact on river flows and catchment hydrology: a comparison of two spatially distributed models. Hydrological Processes, doi: 10.1002/hyp.9480

Wigmosta M.S., Vail L.W., Lettenmaier D.P. 1994. A distributed hydrologyvegetation model for complex terrain. Water Resources Research 30:16651679, doi:10.1029/94WR00436. 